Article

\title{
Genetic Analysis of Geothermal Resources and Geothermal Geological Characteristics in Datong Basin, Northern China
}

\author{
Wenlong Zhou ${ }^{1}$, Xiangyun Hu ${ }^{1, *}$, Shilong Yan ${ }^{2}$, Hongdang Guo ${ }^{2}$, Wei Chen ${ }^{1}$, Sijing Liu ${ }^{1}$ and \\ Chunyan Miao ${ }^{2}$ \\ 1 Institute of Geophysics and Geomatics, Hubei Subsurface Multi-scale Imaging Key Lab, \\ China University of Geosciences, Wuhan 430074, China; wlzhou@cug.edu.cn (W.Z.); \\ chenvy2011@126.com (W.C.); sijingliu@cug.edu.cn (S.L.) \\ 2 Shanxi Geological Engineering Exploration Institute, Taiyuan 030200, China; slyan@163.com (S.Y.); \\ dkyoffice@163.com (H.G.); 15834183856@163.com (C.M.) \\ * Correspondence: xyhu@cug.edu.cn; Tel.: +86-139-9565-0995
}

Received: 8 January 2020; Accepted: 16 March 2020; Published: 8 April 2020

\begin{abstract}
Datong Basin is a Cenozoic fault basin located in the central part of the North China Block with strong tectonic activity. The unique geological environment of Datong Basin is believed to have good conditions for the formation of geothermal resources. Based on the research of the classification, genesis and geothermal geological characteristics of geothermal resources, the geological conditions, seismic activity, volcanic activity, geophysical exploration results, terrestrial heat flow and hot springs in Datong Basin are analyzed. The possibility of the occurrence of geothermal resources in Datong Basin is determined, and the genesis and occurrence mechanisms of geothermal resources in Datong Basin are judged. The results show that Datong Basin satisfies the geological geothermal conditions of the formation of geothermal resources and is of great research value. The formation of geothermal resources in the Datong Basin is affected by the uplift of the Qinghai-Tibet Plateau and the destruction of the North China Craton. The geothermal resources in Datong Basin are formed by the combination of modern volcanic activity and strong inner-plate tectonic activities. The geothermal system is a combination of convective hydrothermal systems and partial melt systems. At the same time, it is concluded that the key research areas for the occurrence of geothermal resources are mainly in the northeastern part of the basin. It is recommended to carry out detailed and comprehensive exploration of the northeastern part of Datong Basin.
\end{abstract}

Keywords: geothermal resources; genesis and occurrence mechanisms; geothermal geological characteristics; Datong Basin

\section{Introduction}

With the constant consumption of global energy, the energy problem becomes more and more prominent. The adjustment of the energy structures, the development of new energy and the utilization of clean energy are of importance in the world. As a new type of renewable energy, geothermal resources have attracted significant attention, thanks to its cleanliness, stability, safety and less impact on the surrounding environment. In addition, geothermal resources have the advantages of higher energy, of being renewable, with a higher utilization rate, better safety and nearly no pollution compared with other energy sources.

Geothermal resources have been used for commercial power generation for more than 100 years. However, only since 1990, the study of geothermal geology theory and geothermal geological law, coupled with the development of geothermal resources exploration technology, have been strengthened 
over the world. The study of geological conditions, geothermal distribution and geothermal formation law, as well as the development and utilization of geothermal resources increased rapidly, resulting in many geothermal power stations have been established in some countries [1]. The study on the exploitation and potential usage of geothermal resources have been carried out in China's provinces of Hainan, Jiangsu, Qinghai, Fujian, Tianjin [2-6]. According to the evaluation of a large number of terrestrial heat flow data, it is concluded that there are plenty of geothermal resources reserves in the mainland of China, some favorable target areas are for example, Bohaiwan Basin in North China, Fenwei Graben in the southeastern margin of Ordos Basin, as well as Songliao Basin in Northeast China [5,7]. Datong Basin is located in the depression of the southeastern margin of the Ordos Basin, which has suitable geological environment for the formation of geothermal resources and it has potential reserve of geothermal resources.

This contribution describes the geological conditions, seismic activity as well as volcanic activity in Datong Basin. The geophysical exploration results, terrestrial heat flow together with hot springs are analyzed. We determine the possibility of existence and genetic mechanism of geothermal resources in the basin. The paper divides the key research areas in Datong Basin, and puts forward reasonable suggestions for further exploration of geothermal resources in the study area. It hopefully provides has important reference value for further research of the genesis mechanism of geothermal resources.

\section{Classification, Occurrence and Genetic Mechanism of Geothermal Resources}

The classification of geothermal resources mainly reflects the genetic mechanism of different geothermal resources. There are many schemes for the classification of geothermal resources, based on the effects of geological controls and heat transfer characteristics. The geothermal energy is divided into convection-dominated geothermal plays system and conduction dominated geothermal plays system. The former can be further divided into magmatic geothermal plays (including volcanic field and plutonic type) and non-magmatic geothermal plays (extensional domains type), while the latter can be divided into igneous geothermal plays and non-magmatic geothermal plays (including intracratonic basins and orogenic belts). The study shows that geothermal resources are affected by plate tectonics, tectonic activity or volcanic activity [8]. Geothermal resources understood as systems can be divided into magmatic geothermal resources and non-volcanic resources based on whether they are related to emplacement of magma or not. The magmatic geothermal systems include convective hydrothermal systems (water or steam dominated), hot dry rock and partial melt systems [9].

Some researchers believe that the formation of geothermal resources is related to the continental orogenic belts (or plateaus) that are active in Cenozoic era and non-uniform rheological behavior of crust stratification in sedimentary basins. In the Cenozoic tectonic activity area, the crustal melts, partially melts, semi-solid and solid rheology to varying degrees, and the (semi-solid) solid rheological material (with little change in density) undergo uneven motion under the action of gravity and bedding shear forces. These substances are upwelling to form heat sources, and heat conduction transfers abnormal heat energy to the upper strata through heat-controlled structures, forming an ideal target area for geothermal resources $[10,11]$.

The occurrence of geothermal resources is mainly in the following areas: the high radioactive heat production zone, the sedimentary basin and the modern volcano zone as well as the inner-plate active tectonic zone $[12,13]$. Geothermal resources in the high radioactive heat production zone is mainly due to the development of many large-scale Mesozoic acid granitoids in the shallow surface of the Earth's surface and crust. This type of rock mass has high radioactivity heat production characteristics and can obtain good geothermal resources under ideal heat production and overburdened thickness conditions. Geothermal resources in the sedimentary basin are mainly due to the low thermal conductivity of the thick depositional overburden, which prevents the heat loss from the deep heat source. In the modern volcano zone geothermal resources are closely related to volcanic activity, mainly in areas with strong volcanic activity. Under the action of tectonic activity, mantle-derived magma is partially melted and magma diapir rises. When magma intrudes into the crust, it extends laterally and forms a 
flat round magma chamber. At the same time, it forms a tension stress field on the surface, which leads to the rupture of rock formations and the formation of craters. After the volcanic eruption, the magma passages gradually cool down. However, the unexploded magma moves along the tectonic fissures and forms magma sacs, which are the heat source for the formation of geothermal resources [14,15]. Geothermal resources in the inner-plate active tectonic zone mainly refer to the influence of tectonic activity. Under the action of tectonic activity, the original tectonic pattern changes, strata uplift, crustal compression and thickening. The crust partially melts under the action of inter-plate compression, and magma underflows locally. The heat source generated by partial melting transfer heat energy to shallow strata through large faults to form geothermal resources. They have similarities in heat sources between the modern volcano zone and the inner-plate active tectonic zone. Both of them have high temperature melt as the heat source is in the middle and deep crust, which causes shallow thermal anomalies [12,16]. In terms of genetic mechanism, the formation of these two types of geothermal resources originates from the high temperature heat source in the middle and deep crust.

Although different scholars have different expressions on the classification and genetic mechanism of geothermal resources, the genesis of geothermal resources are described as the upwelling of heat sources in the deep crust along the heat conduction channel and the storage of heat in rocks in different ways. At the same time, it is concluded that the formation of geothermal resources is related to tectonic activity, magmatic intrusion, volcanic activity and radiative activity of granite [13,17-21].

\section{Datong Basin}

\subsection{Geological Condition}

Datong Basin is a Cenozoic fault basin located in the central part of the North China Craton, NCC), which is divided into the Eastern Block (EB), the Western Block (WB), and the Trans-North China Orogen (TNCO) [22]. Datong Basin stands on the junction of Trans-North China Orogen (TNCO) and the Western Block, which has undergone continuous and intense extensional action since the late Miocene (Figure 1a). The regional dynamics of the formation and evolution of Datong Basin may be result of combined action of the Indian-Eurasian plate and the Pacific-Eurasian plate collision [23-25], which corresponds to the craton destruction in the central and western parts of North China Craton, mainly due to the mantle activity and the thinning of the lithosphere [26-30].

The main mechanism of the destruction of the North China Craton is the subduction of the Pacific plate [24]. It is believed that the subduction of the Paleo-Asian Ocean to the North China in the Late Paleozoic, the subduction of the Early Mesozoic Yangtze to the North China, and even the subduction of the Indian plate to the Eurasian continent can cause the partial transformation of the weak tectonic belt in the central-western part of the North China Craton or the thinning of the lithosphere, and the upwelling of the asthenosphere [26,31,32]. In the Cenozoic thermal tectonic events, the lower intensity active tectonic belt is more likely to become the area where the heat is more intense and the stress changes are concentrated, thus its lithosphere is more vulnerable to transformation, weakening and thinning [26,33]. The alteration and thinning of the lithosphere are mainly characterized by magmatic activity in the deep part, and extensional activity in the shallow part [34]. The lithosphere in Datong area has a demolition effect, asthenosphere upwells, mantle thermal erosion occurs from bottom to top, and mantle uplifts. Magma formed by partial melting of the upper mantle transfers heat to the crust. The tectonic stress field reaches the strength of crustal rupture in the shallow and lateral extension which occurs in the heated crust [35-37]. The heat source material surges, the crust expands and thins, and high temperature anomalies are formed upward, providing a heat source for the formation of geothermal resources. Fundamentally, the strong collision between the Indian plate and the Eurasian plate caused the uplift of the Qinghai-Tibet Plateau. Under the action of the Qinghai-Tibet Plateau uplift and the eastward extrusion, the volcanic activity and tectonic uplift occurred in Datong Basin, forming a series of graben-type fault basins with internal secondary uplifts and depressions [38]. The Datong Basin is located in the continental crust extensional fracture area. Normal fault tectonic 
stress field controls the activity of boundary faults and the formation of basins. The tectonic zones around the basin cause regional crustal deformation, compression and thickening under the action of tectonic stress. Decompression and melting occur under the action of inter-plate compression to form partial melt body, which provides favorable conditions for the formation of geothermal resources.

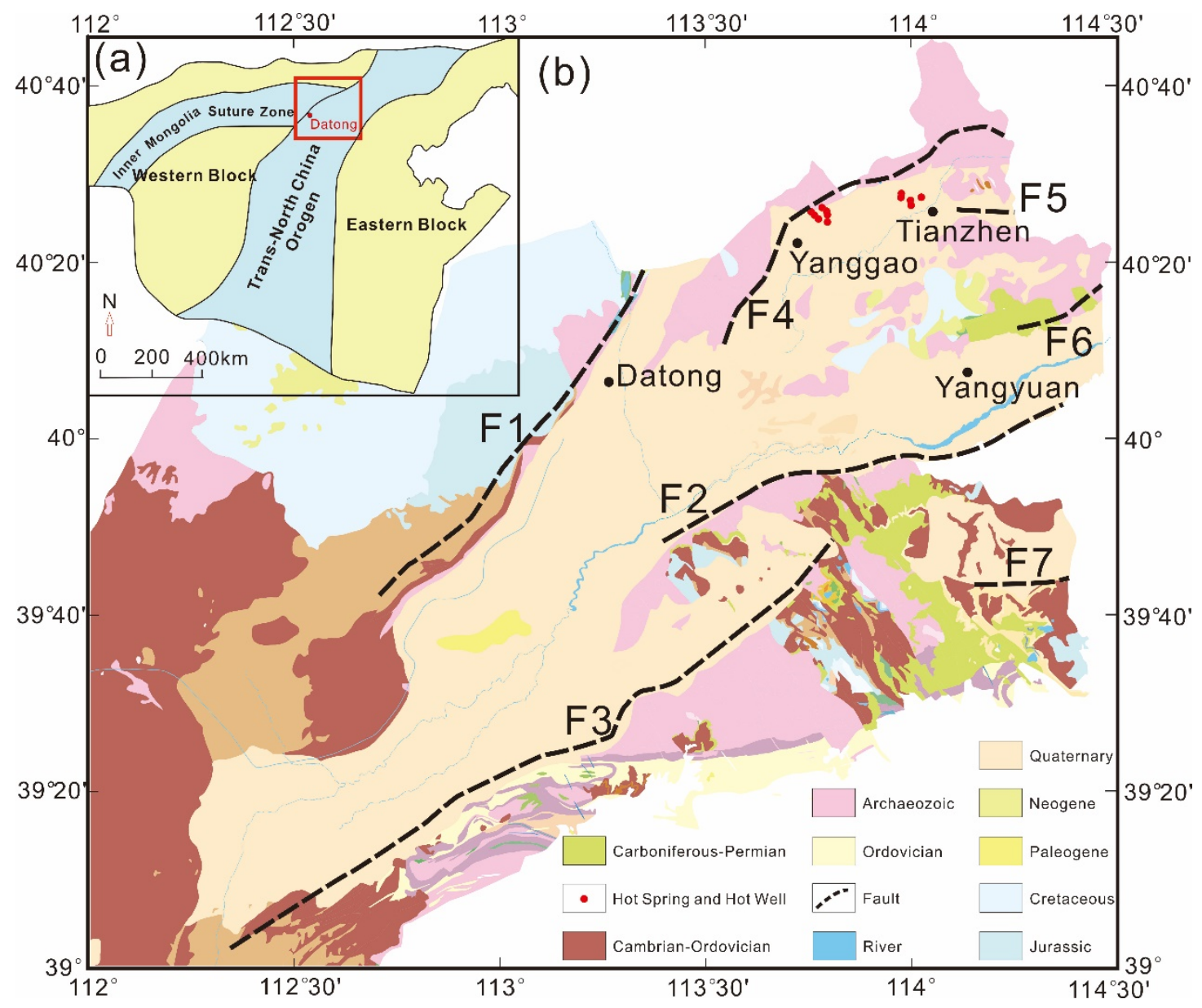

Figure 1. (a) Topography map of North China Craton. The rectangle area with red solid line in (a) is the study area (Datong Basin). (b) Geological Map of Datong Basin.

Datong Basin's basic tectonic framework was formed in Mesozoic. The faulting activities of Datong Basin were mainly controlled by boundary faults, forming a series of grabens and semi-grabens. Tectonic movement is dominated by fault structure, followed by fold structure. The main fault direction is NE, but the local geometry, fracture and movement characteristics of the fracture are complex. Major boundary faults include (Figure 1b): Kouquanshan fault (F1), Liulengshan fault (F2), Hengshan fault (F3), Yunmenshan fault (F4), northern margin fault on Xionger Mountain (F5), southern margin fault on Xionger Mountain (F6), Xiaowutaishan fault (F7), in the same breath, and there may be buried faults in this area $[24,39]$. In boundary faults, the strike of fault F1 is NNE direction, while that of other faults is mainly NEE. The boundary faults movement in Datong Basin is mainly characterized by vertical movement and extension movement. Only fault F1 has an obvious right-sliding motion component, the depth of the faults in the Datong basin is larger, in which the Hanbuoba basalt is cut in the north of fault F1. Fault structures directly control the distribution of geothermal energy, especially the existence of deep and large faults, which provides a pathway for magma from upper mantle melting to shallow crust. The regional deep-large faults in Datong Basin extend downward and intrude into igneous rock mass along the shallow part of the deep-large faults. There are favorable channels to connect the shallow part with the deep heat source, and transmit the high-temperature materials in deep 
underground through the large-scale structural faults to the upper stratum. The main direction of the faults activity in the Datong Basin is NE, therefore the direction of heat conduction is also along the NE direction. When the conditions of the upper cover are ideal, geothermal resources can be formed in the northeastern part of the basin.

\subsection{Volcanic and Magmatic Activities in Datong Basin}

The Datong Volcanic Group is the only volcanic group developed on the Loess Plateau in the world. The magma of the Datong Volcanic Group originates from the primitive basalt magma melted in the upper mantle $[40,41]$. In the early Quaternary period, the deep fault activity led to the decompression and melting of the mantle. During the intense activity of the upper mantle, the upper mantle material near the fault zone erupted along the fault, and the neotectonic movement formed a fault deep into the upper mantle and triggered the volcano activity. Datong's volcanic activity began in the late Early Pleistocene, mainly in the Middle Pleistocene, and lasted until the early Late Pleistocene, which was related to the lithosphere-asthenosphere interaction caused by asthenosphere upwelling [42]. After the eruption of Datong volcano, the magma channel gradually cooled, but the unexploded magma migrated along the tectonic fault to form a magma sac. The structural faults in the basin are basically along the NE direction, so the unexploded magma is also collected in the northeastern part of the basin law, formed as heat source for geothermal resources. Datong volcanic group can be roughly divided into North and South regions. Volcanic activity in the south region is earlier than that in the North region. Volcanic cones in the northeast of Datong County are relatively dense and formed later. Combining with the distribution of magmatic rocks in the map (Figure 2), it is concluded that the center of the magmatic active volcanic group in the study area migrates to NE direction. In Datong and Yangyuan, the discovery of mantle mites further proves that the magmatic activity in the study area is intense and the magma comes from the upper mantle [24].

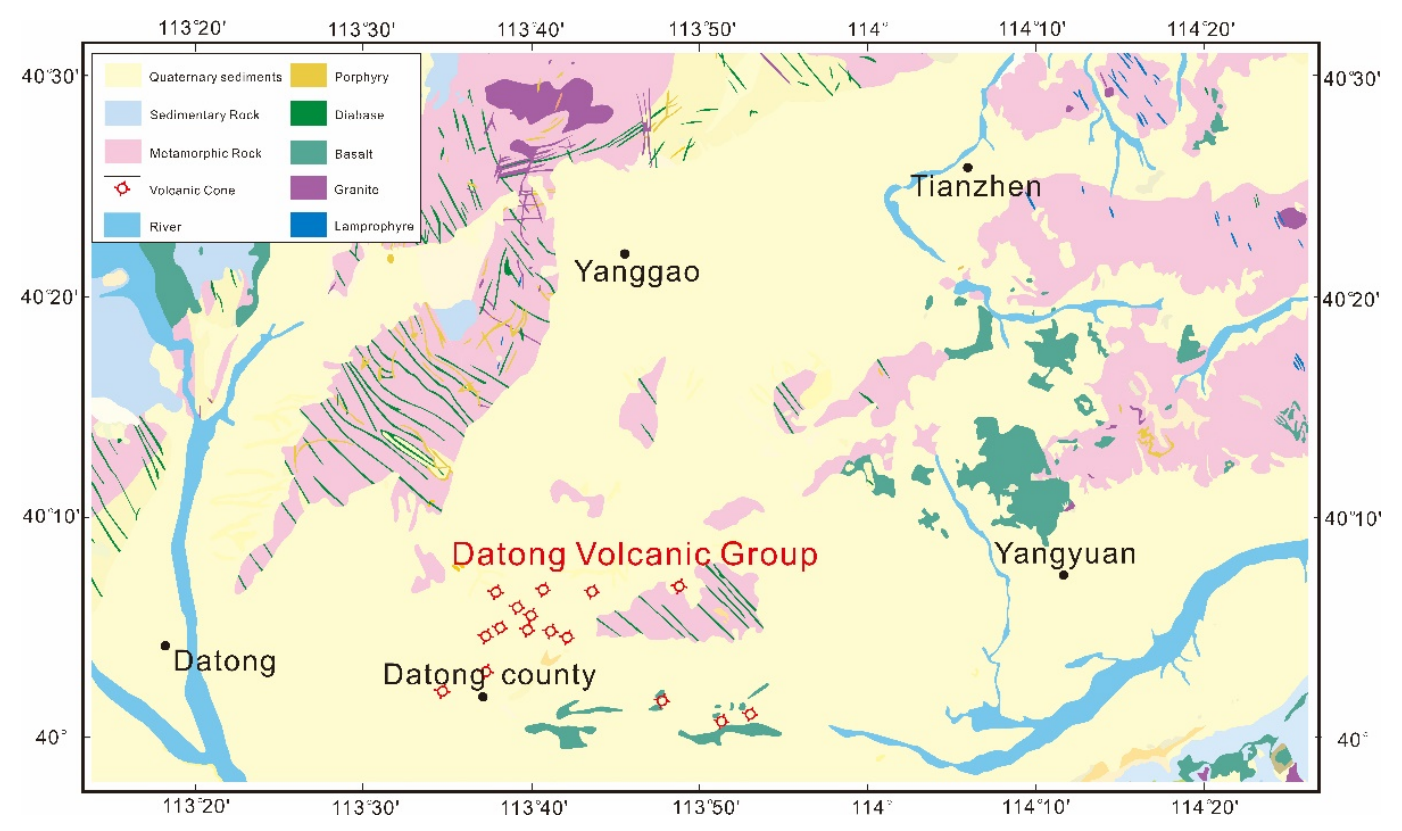

Figure 2. Datong Volcanic Group and distribution of magmatic rocks.

The magmatic rocks in Datong area are well developed and distributed with a large number of Cenozoic basalts. Basalts originate from the mantle and provide information on lithospheric structure and mantle activity. The eruption of basalts reflects that the lithospheric structure in Datong area has been destroyed, and the destroyed lithospheric structure is the basis of basin formation [35]. As shown in the Figure 2, the magmatic rocks in Datong Basin are mainly distributed in the periphery of the basin and in the south of the basin, mainly concentrated in the vicinity of the deep-large faults, 
while the magmatic rocks in the Tianzhen and Yanggao areas in the northeastern part of the basin are less exposed. It is inferred that the area is a magmatic unexploded area with magma sacs or high temperature anomalies in the deep part, which may be a good heat source convergence area.

\subsection{Seismic Activity}

The distribution of earthquakes and geothermal resources are spatially coincided. They are concentrated on the boundary of plate tectonics [10]. Plate tectonic framework controls thermal state, heat flow, hydrogeological conditions, stress state, fault and lithology of rock strata, which are essential factors for the formation of geothermal resources [8]. Earthquakes reflect the process of accumulation and release of energy. The seismic activity is closely related to inhomogeneous thermal activity in the interior of Earth [43]. Energy released by earthquakes is mostly converted into mechanical energy, which can not constitute the heat source of geothermal system. However, the heat source of geothermal resources comes from the interior of earth, because of the high failure of rock fracture when earthquakes occur, the deep heat source material is more easily to flow up to the shallow stratum and form geothermal anomalies. The locations where earthquakes occur are mostly in active crustal zones or active plate margins, which are consistent with inhomogeneous flow of thermal materials in the crust and mantle. Therefore, these high-frequency seismic sites have strong tectonic activities which are associated with the formation of geothermal resources. There is a certain sequence relationship in time, closely related in genesis as well as a certain spatial consistency in distribution.

Datong Basin is located in the thin crust structure of North China, which is related to mantle diapirism. There may be an asthenospheric upwelling column in Datong area, which has a strong influence on the upper lithosphere. The main manifestations are the Moho surface uplift and the crustal extension thinning, tensile basin development, magmatic activity, frequent earthquakes, geothermal gradients, positive anomalies, etc. [10,43,44]. It also indirectly shows that the distribution of earthquakes is consistent with spatial distribution of geothermal resources. Datong Basin is located in the northern part of Shanxi fault depression zone. From Figure 3, we can see that small and medium earthquakes occur frequently in Datong Basin. There are seismic activities in the entire basin which is controlled by boundary faults. The earthquakes are concentrated near the boundary fault, and it is basically a shallow earthquake of about $10 \mathrm{~km}$ [45]. Earthquakes with Ms5 or above are mainly located near the middle part of fault F2, mainly in Yangyuan earthquake area. Earthquakes below Ms5 are mostly located near fault F2 and F5 in Yanggao-Tianzhen earthquake area. From the frequency of earthquake occurrence, the seismicity mainly occurs in the northeastern direction of the Datong Basin, located in the Yanggao and Tianzhen counties, near the edge of plate activity. The frequent occurrence of earthquakes also indicates that the structure of the area is relatively new and the tectonic activity is strong. It is precisely because of these frequent geological activities that provide a steady stream of energy for the geothermal anomaly area in the basin, which is conducive to the formation of geothermal resources. 


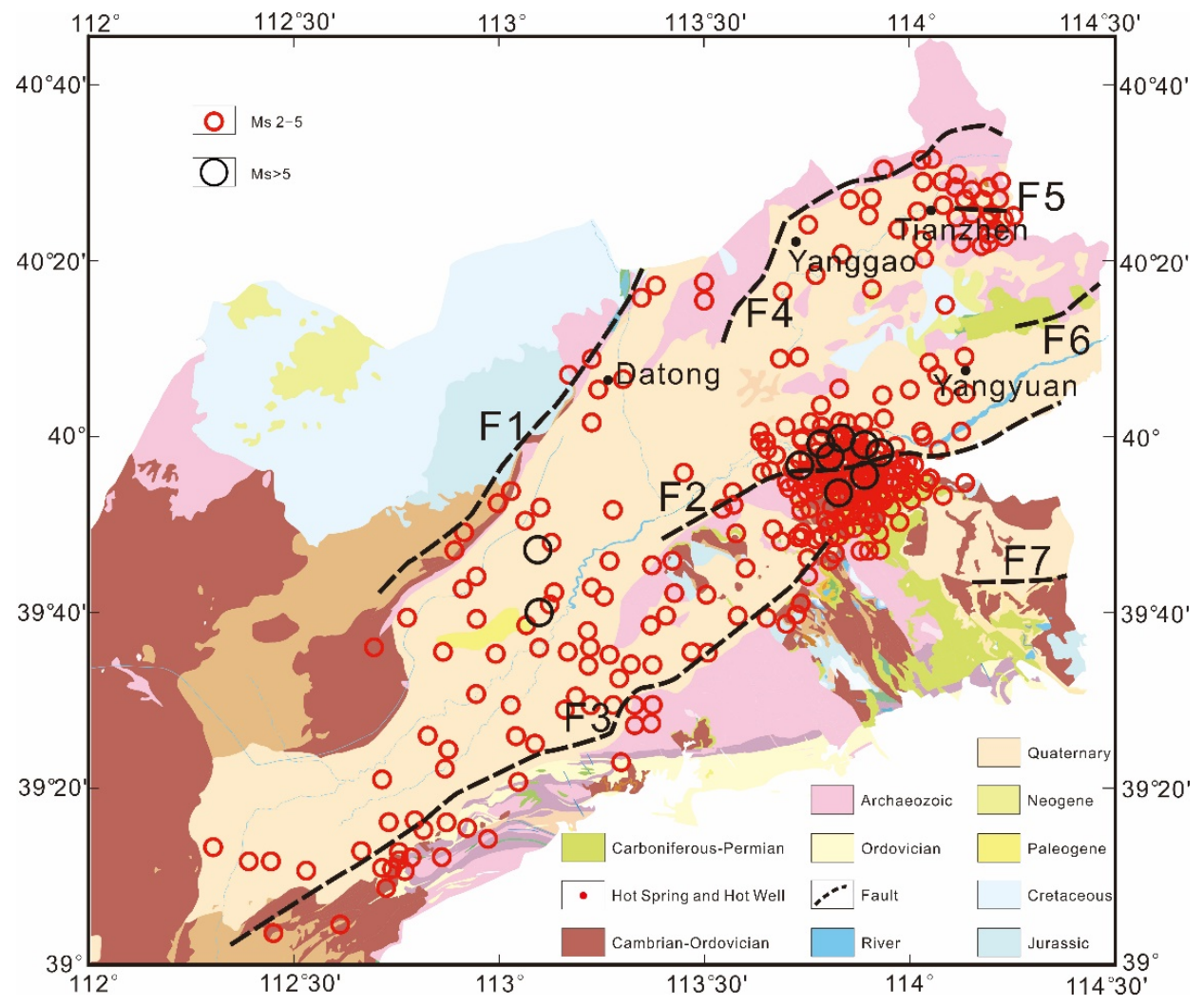

Figure 3. Distribution of earthquakes in Datong Basin [46,47].

\subsection{Geophysical characteristics of Datong Basin}

Under specifically geological conditions, the underground strata form geothermal resources, and the characteristics of geothermal resources (high temperature, high pressure, etc.) directly or indirectly affect the petrophysical properties of the reservoir itself and its adjacent strata (such as resistivity, magnetic susceptibility, elastic wave velocity, etc.). This is the basis to use geophysical methods to delineate geothermal resource. At present, the commonly used methods of geothermal resources exploration include gravity method, magnetic method, electrical method and seismic method [35-38]. These methods can be used to detect the favorable conditions for the formation of geothermal resources, including the morphological characteristics, extent, thickness and other information of geothermal anomalies; the upper mantle depth, or the depth of Curie isotherm surface, the position of the magma pocket and other heat source information; position detection of deep thermal conduction structures is also included. For this reason, the storage area of geothermal anomalies can be indirectly judged by some geophysical characteristics.

Therefore, based on the comprehensive analysis of geophysical data in Datong Basin and its surrounding areas in recent years, the geophysical characteristics of geothermal resources are discussed, which can provide more information for prospecting geothermal resources.

\subsubsection{Magnetotelluric (MT) and Seismic Detection Results}

As shown in the Figure 4, the picture shows the MT and seismic lines of Datong Basin and its surrounding, covering the entire Datong Basin. In Figure 5, when the depth is $5 \mathrm{~km}$ in Datong Basin, the whole upper crust generally shows high resistivity layer with resistivity of about $3000 \Omega \mathrm{m}$. At the depth of $20 \mathrm{~km}$, the high and low resistivity alternate and distribute in strips and Datong Basin is in a state of low resistivity. Combined with the profile P1 and P2, there is a low resistivity anomaly C1 at the lower of Datong Basin, which invades the upper high resistivity body and forms a low resistivity body response on the shallow surface. The low resistivity body on the shallow surface is located below 
the Datong volcanic group. According to the MT study of the volcanic area, it is revealed that the deep low resistance can indicate the distribution of the melt or magma [48]. It is inferred that $\mathrm{C} 1$ is the mantle source (partial melting zone) of the Quaternary volcanic activity of the Datong volcano. The magma produced by part of the melt migrates along the deep fault F1 to the crust. Under the action of the extension and deformation of Datong Basin, a wide range of basalt flows and volcanic cones are formed [39]. The unexploded magma converges and forms high temperature anomaly bodies in Datong Basin, which provides heat source for geothermal resources. At the same time, there is an important low resistivity body located between Hannuoba field and Datong volcano in the depth of 30-80 km, which has a tendency of upwelling and is connected with the low resistivity body C1 of the middle crust under Datong volcano [49]. Partial upward flow of the asthenosphere leads to decompression and partial melting. The melt is in the SW-NE direction and penetrates upward through the crust, so that the Datong volcanic lava erupts to the east, and some magma does not erupt and migrate along structural faults, forming high-temperature anomalous bodies, providing heat source for the upper dense rocks.

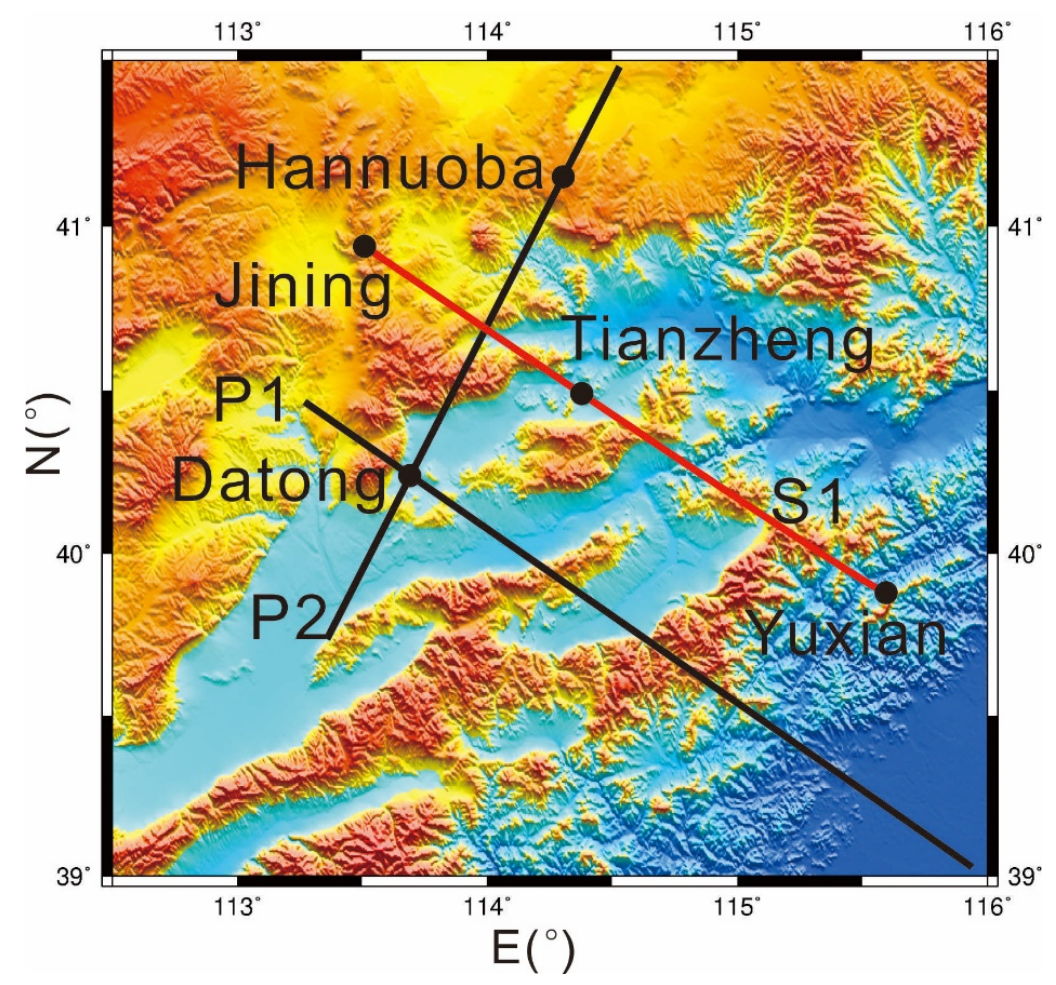

Figure 4. Distribution of MT and seismic profiles in Datong Basin and its surrounding areas. P1 and P2 (black solid lines) are slices of magnetotelluric (MT) three dimensional inversion results [49]. S1 (red solid line) is a seismic line [50].

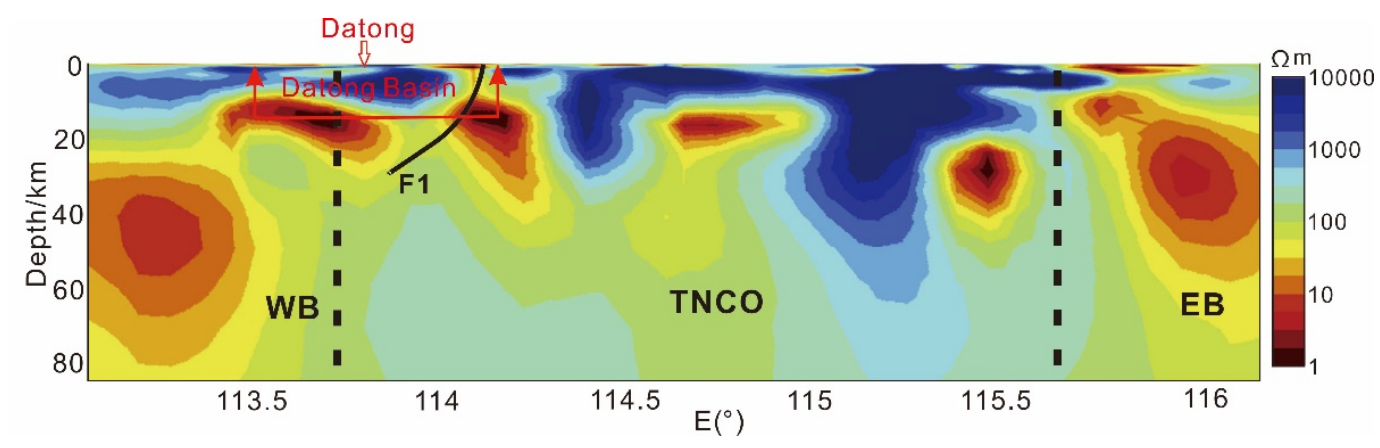

(a)

Figure 5. Cont. 


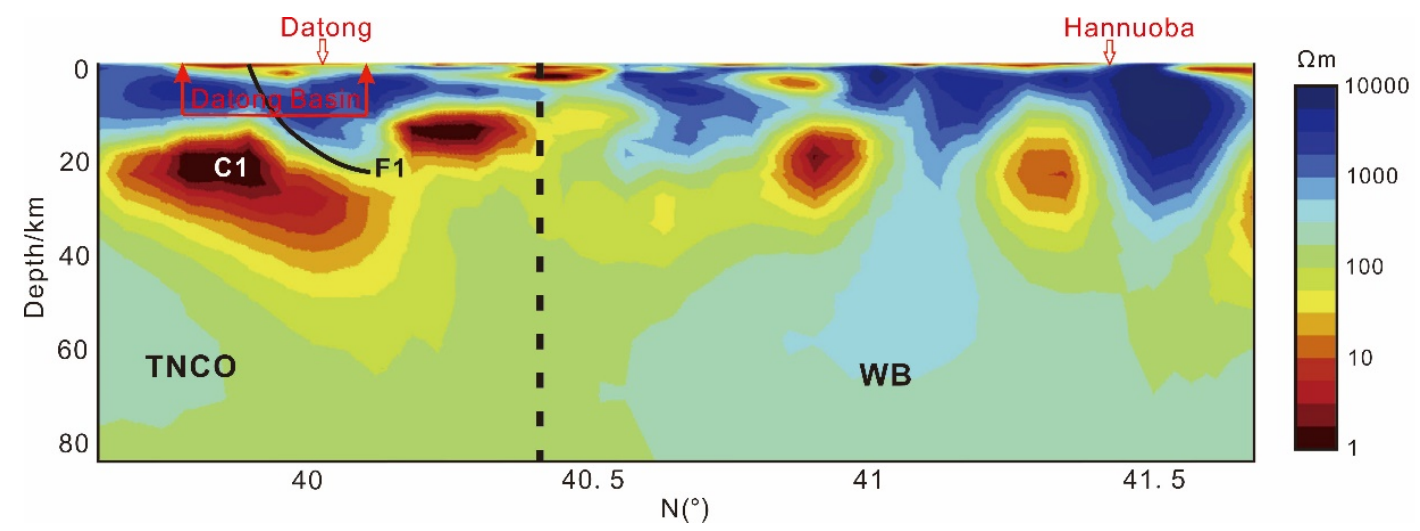

(b)

Figure 5. Inversion results of MT (redrawn from [49]). (a) Vertical slice along profile P1; (b) Vertical slice along profile P2.

In Figure 6, the profiles indicate that there is a low-velocity anomaly L1 below Datong Basin, which is consistent with the surface wave imaging results in this area and extends downward to the mantle [51]. The local area of L1 shows stronger anomalous amplitude, which corresponds spatially to the surface of the Datong volcano. Temperature and material composition are the two most important factors affecting wave velocity anomaly, and temperature is the most important factor affecting the upper mantle velocity anomaly $[31,52,53]$. The effect of material composition on temperature is secondary in the depth of $400 \mathrm{~km}$, the low velocity characteristic of L1 is mainly affected by temperature, indicating that L1 has a very high temperature. The researchers believe that L1 may reflect the partial melting of the upper mantle. There is a horizontal mantle flow below Datong basin, causing the mantle to rise and lead to volcanic activity. Investigators $[31,54]$ infer that L1 may reflect the partial melting of the upper mantle below Datong Basin, causing the mantle to rise and lead to volcanic activity. The results of seismic exploration are consistent with those of MT detection in Datong Basin. Under Datong Basin, there are partial melts, which provide a stable heat source for the formation of geothermal resources.

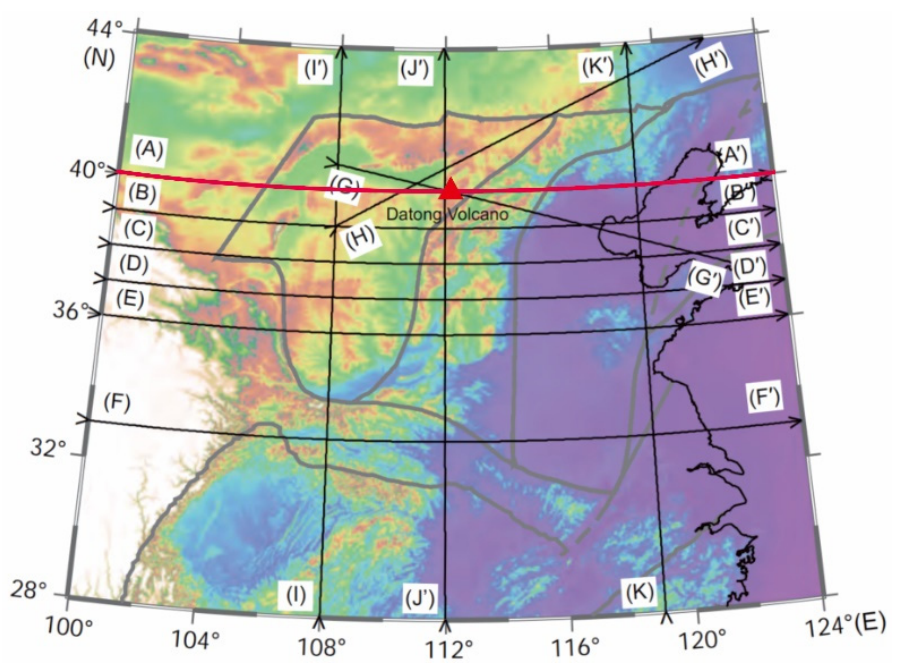

(a)

Figure 6. Cont. 


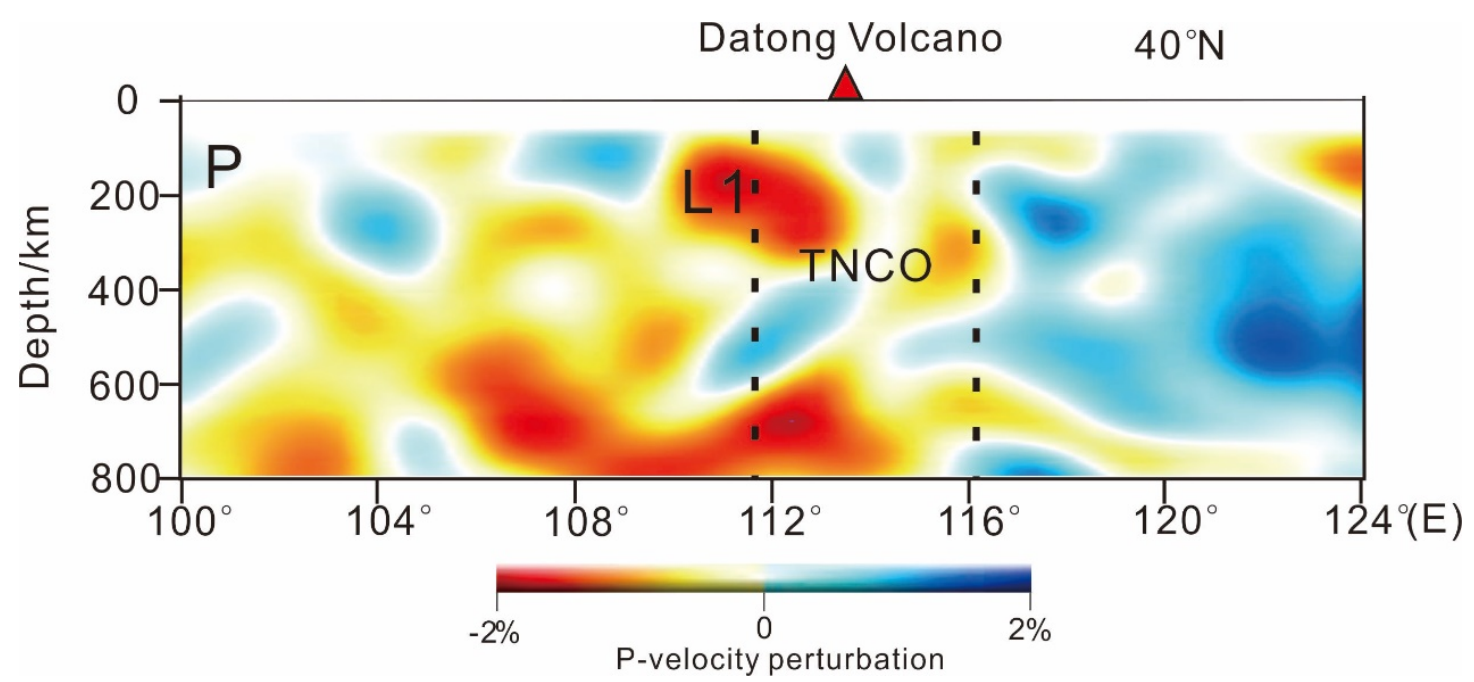

(b)

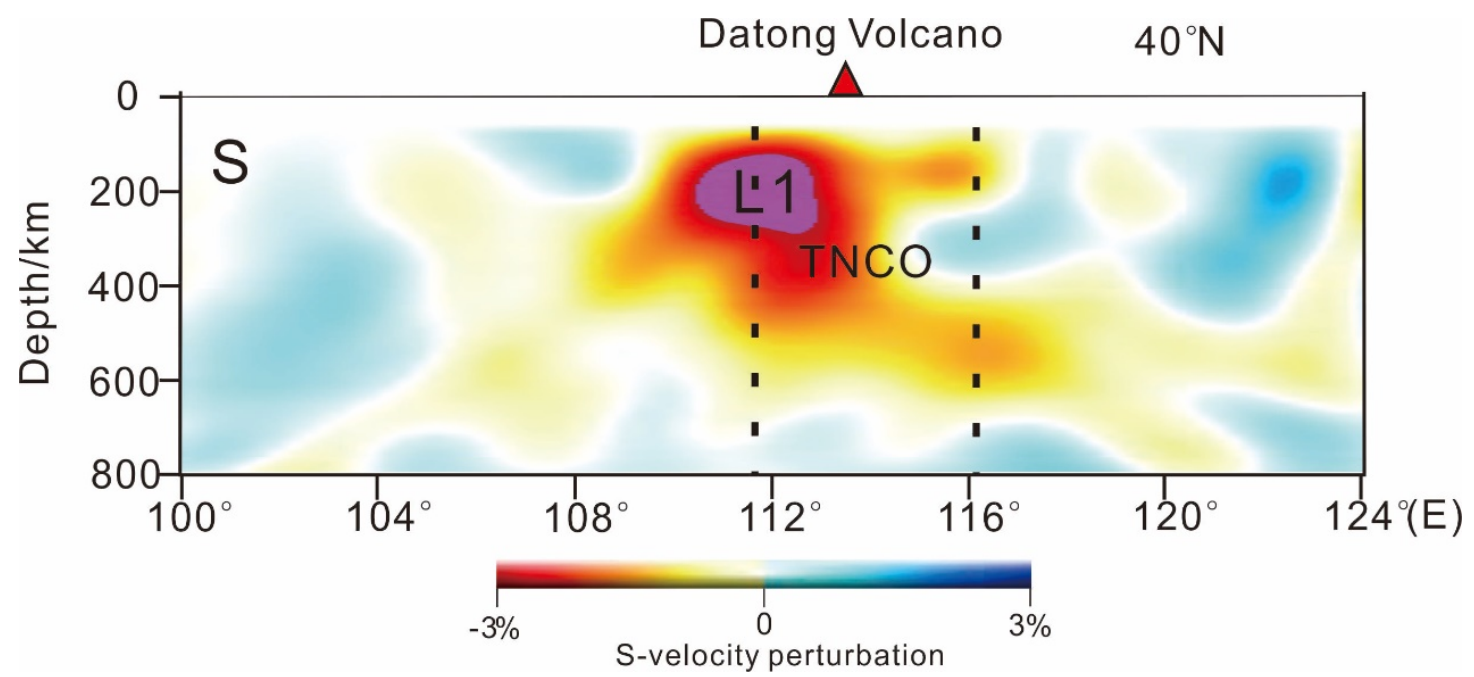

(c)

Figure 6. Vertical slices of three dimensional inversion results (redrawn from [31]). (a) The location of seismic survey (red line); (b) Vertical slices of the P-velocity model; (c) Vertical slices of the S-velocity model.

Figure 7 is a seismic profile passing through the northern of Datong Basin (S1 in Figure 4). Profile S1 illustrates the structure and tectonic features of the crust-upper mantle in Tianzhen area. It can be seen that there is low velocity anomaly in the middle crust and the upper crust, which is a separate closed circle, and the low-velocity anomaly is basically distributed in Tianzhen area with high terrestrial heat flow value. The S-wave velocity at the top of the upper mantle has changed significantly, and terrestrial flow value in Tianzhen County is high, and the structure and magmatism are intense, which may indicate the existence of thermal anomalies in the deep. According to the S-wave exploration results, the Moho surface burial depth in the Tianzhen and Yanggao areas of Datong Basin is $38 \mathrm{~km}$, while that in the mountainous areas on both sides is $42-43 \mathrm{~km}$. The hot melting unit of Moho surface uplift zone in the basin is $71 \mathrm{mv} / \mathrm{m}^{2}$, which indicates that there is a stable geothermal source in the lower part of the basin.

\subsubsection{Gravity and Magnetic Characteristics of Datong Basin}

In Figure 8, the magnetic fields in Datong Basin are generally NE-trending, consistent with the basic tectonic framework in the area. According to the regional aeromagnetic data, the Yanggao-Tianzhen 
area is a disordered magnetic field area. The background field is a positive magnetic field, there are local magnetic anomalies, there are positive and negative anomalies alternating phenomenon, the anomaly intensity is 200-300 nT. Because the basement is cut by Mesozoic and Cenozoic faults into several blocks of different sizes and elevations, the magnetic field appears to be abnormally positive and negative, and several narrow negative anomalies in the area are reflections of fault block collapse. Therefore, it is considered that the delineation range of Tianzhen-Yanggao anomaly is favorable for searching for geothermal resources related to the intrusive rock mass.

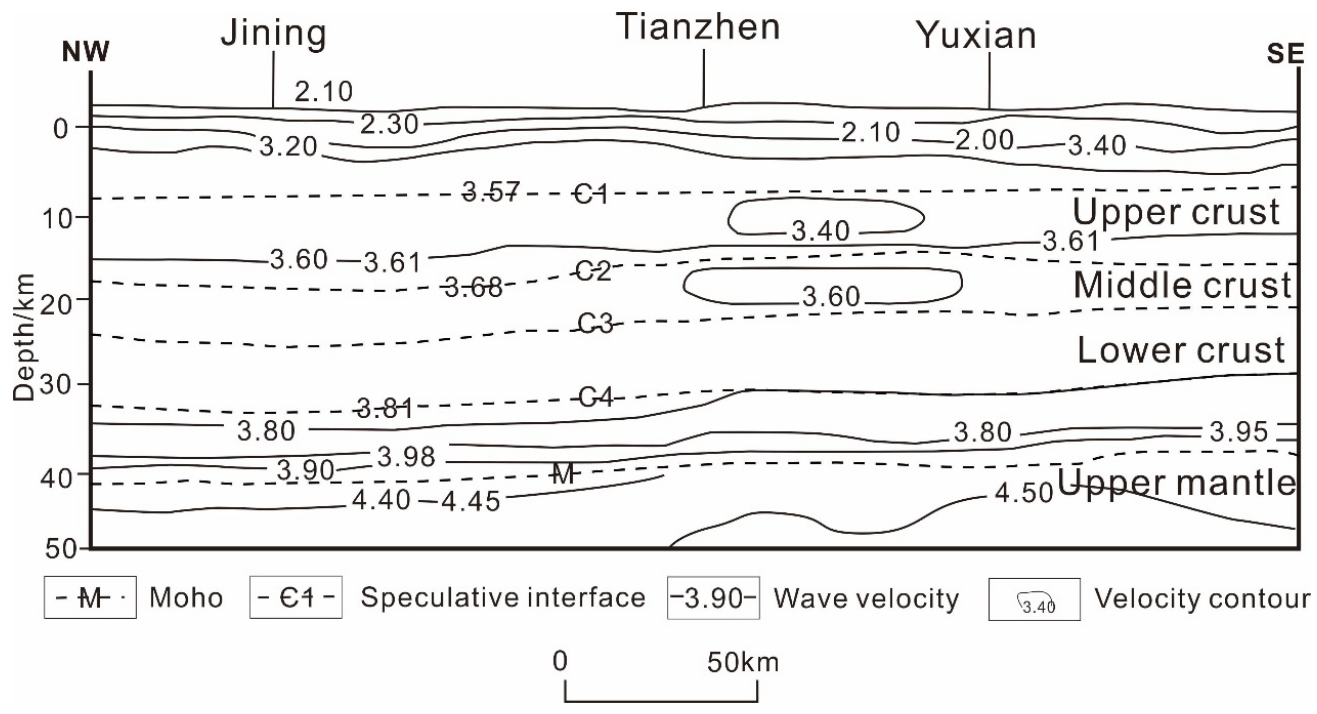

Figure 7. The seismic exploration result of profile S1 [50]).

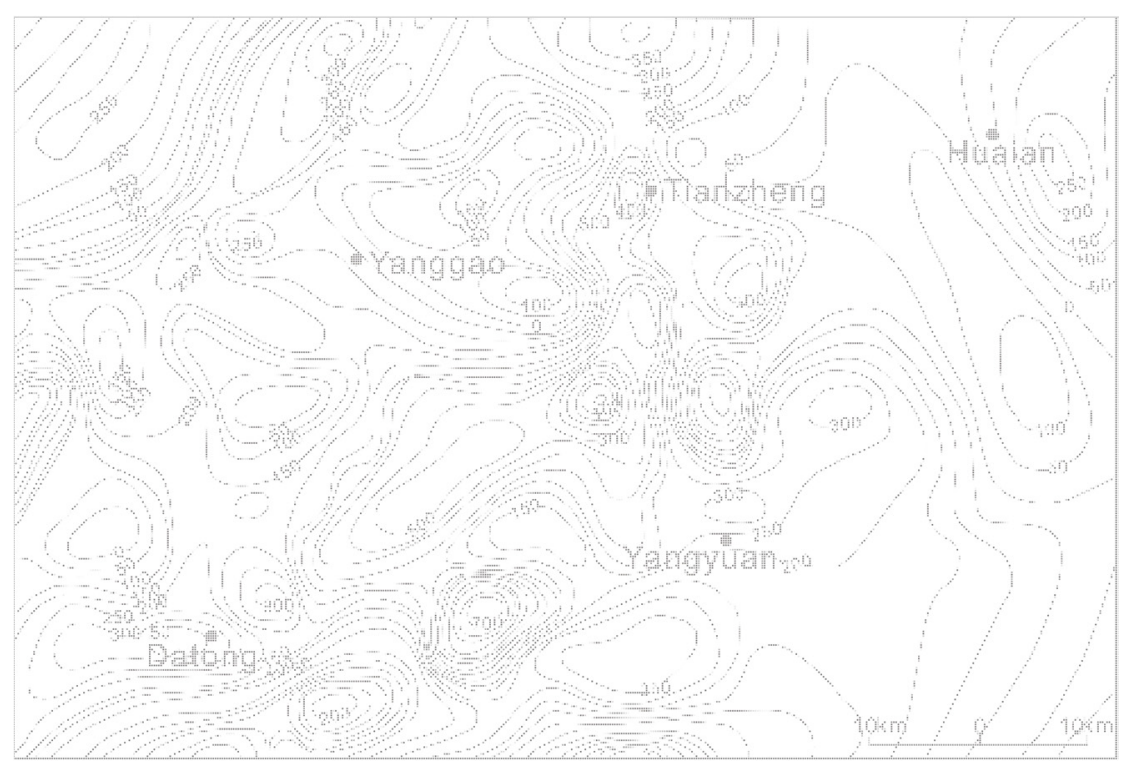

Figure 8. Aeromagnetic anomaly contour map of Datong Basin.

In addition, we use satellite gravity and magnetic data to study Datong Basin and its surroundings. Figure 9a,b shows Bouguer gravity anomaly and magnetic anomaly. We determined the black rectangle in the graph as the key research area by the regional gravity and magnetic data. In order to better identify the gravity and magnetic anomalies, we processed the theta map and Tilt for the gravity and magnetic data, as shown in Figure 9c-f. In Figure 9, the regional gravity magnetic field is generally distributed in the NE direction, which is consistent with the basic structural framework in the area. 
Gravity gradient zone reflects the distribution of fracture to a certain extent, and the gradient zone of positive and negative anomalies corresponds well to active faults in basin. The effect is more obvious with the boundary recognition. Generally, mantle uplift should cause positive gravity anomaly. It can be seen from the figure that there are obvious positive gravity anomalies around the key research area, which may be caused by the mantle uplift. Tianzhen-Yanggao area is converted into a low gravity area, which passes through the Archean gneiss. The center of the anomaly is the Cenozoic, the northwest is the Archean gneiss, and the eastern and southern parts are exposed by the Archean gneiss. According to the regional gravity data, the characteristics of the marginal gradient of the anomaly range and the location of the structure, it is inferred that the anomaly is not only caused by the depression of the interface between Cenozoic and Archaean gneiss, but also affected by the deep low density body, which is estimated to be a large-scale intrusive rock mass. It shows that the mantle source materials intrude into the inner part of the basin along the faults and mainly concentrate in the key research areas. The magnetic survey data is relatively cluttered. It is speculated that the lithosphere thinning in the region since the late Mesozoic, and the upwelling of the asthenosphere in the later period, resulting in sustained strong stretching. Furthermore, it can be judged that the crust of the Datong Basin is thinned under the action of stretching, and the heat source material is upwelled, which is conducive to the occurrence of geothermal resources.
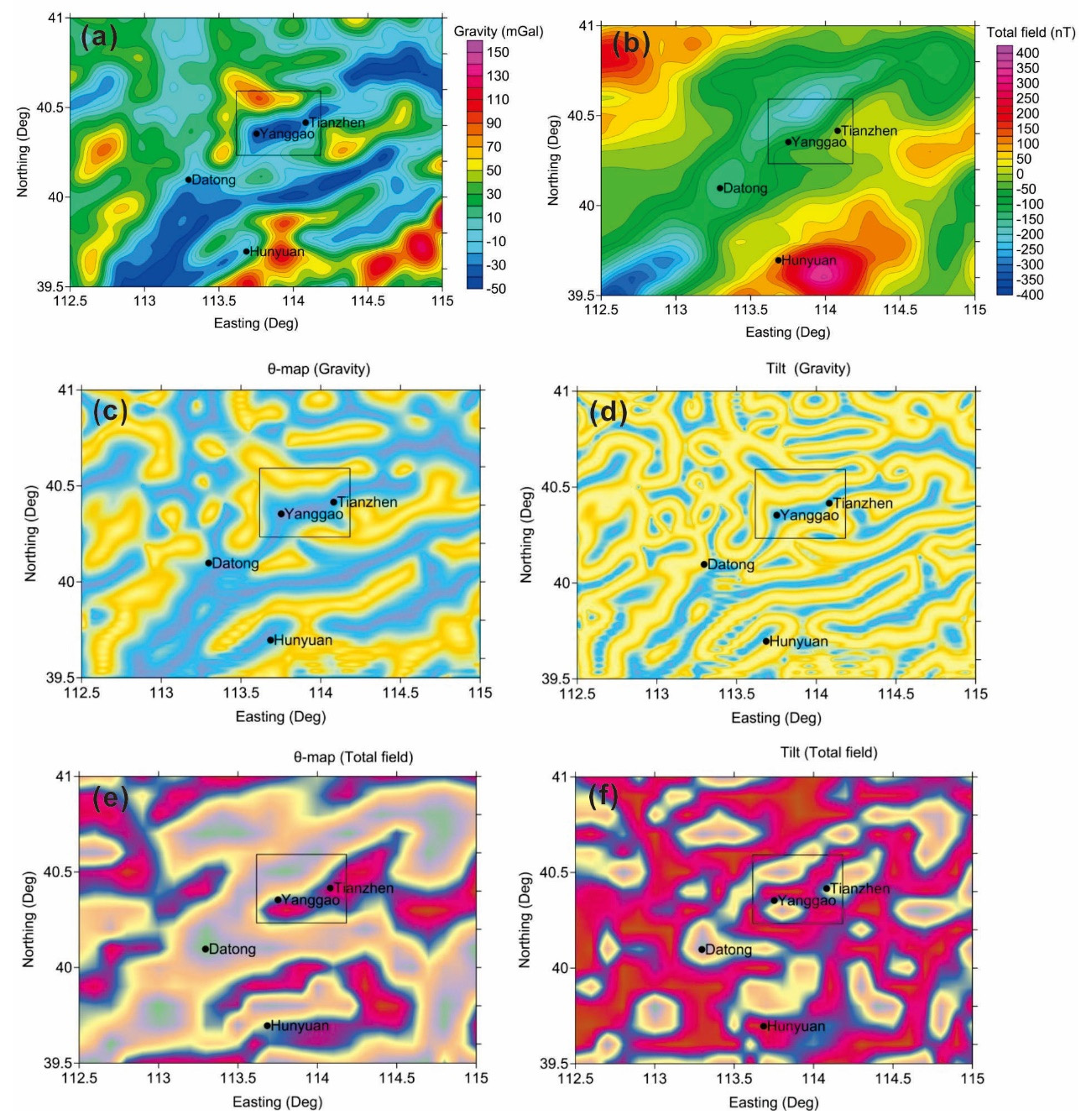

Figure 9. (a) Bouguer gravity anomaly. (b) Magnetic anomaly. (c) Gravity data processing results after theta map processing. (d) Gravity data processing results after Tilt processing. (e) Magnetic data processing results after theta map processing. (f) Gravity data processing results after Tilt processing. The rectangle area with black solid line is key research area of Datong Basin (Yanggao-Tianzhen area). 


\subsection{Terrestrial Heat Flow Value and Hot Springs in Datong Basin}

Terrestrial heat flow is referred to as thermal flow which is a phenomenon of heat transfer from the earth's interior to the surface. It is the most important characterization of the geothermal field [12,28]. Terrestrial heat flow is a directly measurable parameter related to regional thermal characteristics. Its value is closely related to the heat transfer process and tectonic action existing inside the earth [29]. In the light of terrestrial heat flow, we can further analyze the geothermal structure, thermal state and lithospheric rheological structure of the upper mantle, which can reflect the geodynamic properties of the lithosphere.

The Curie isothermal surface is the interface where the temperature of the object reaches a certain height and loses its magnetic properties. It not only indicates the distribution characteristics of the underground temperature field, but also provides the deep thermal stress field of the crust. For the study of the crustal thermal structure, the decrease of depth of the Curie isothermal surface may represent the upwelling of the mantle, which is an important sign of mantle-derived heat generation [33]. The depth variation characteristics of the Curie isothermal surface in China continental area better reflect the deep tectonic framework and the geothermal gradient variation law of deep lithosphere. After many years of research, it is confirmed that the Curie isothermal surface in the stable craton block area is a deep block-shaped depression area, which is mainly reflected as a shallow regional uplift area in the active orogenic and magmatic rock development areas [34].

The Curie isothermal surface and terrestrial heat flow are important characteristics of the occurrence of geothermal resources, terrestrial heat flow is a comprehensive indicator of thermal state of the shallow crust and the most important parameter for deep temperature calculation. Additionally, the Curie isothermal surface also acts as a temperature interface between the lower crust and even the upper mantle with a very close relationship with terrestrial heat flow. Terrestrial heat flow value and the geothermal gradient have a weak negative correlation with the depth value of the Curie isothermal surface, but they do not have a simple linear relationship. As the depth of Curie isothermal surface increases, the geothermal gradient and the terrestrial heat flow value are significantly reduced. Curie isothermal surface and terrestrial heat flow complement each other and are of great significance to the study of geothermal resources occurrence.

The depth of Curie isothermal surface in Datong Basin is about $20-26 \mathrm{~km}$, which is shallower than the depth around the basin. The shallower Curie isothermal surface represents the possible mantle uplift, which is an important indicator of mantle-derived heat generation, so it is inferred that there is mantle uplift under Datong Basin and provides heat source upward. Datong Basin's terrestrial heat flow value is much larger than that in the surrounding mountainous area $\left(37.7-46.1 \mathrm{~mW} / \mathrm{m}^{2}\right)$. These values in are in the range of $75.3-79.5 \mathrm{~mW} / \mathrm{m}^{2}$, which is higher than the average terrestrial heat flow value $50-65 \mathrm{~mW} / \mathrm{m}^{2}$ [55]. Therefore, the Datong Basin is a geothermal anomaly area. In Datong Basin, the areas with high terrestrial heat flow value mainly concentrates in Tianzhen and Yanggao, and the depth of the Curie isothermal surface is smaller. Based on the analysis of the depth Curie isothermal surface and the terrestrial heat flow value in Datong Basin, it is inferred that there may be geothermal resources in the basin, which are concentrated in Tianzhen and Yanggao.

When there are geothermal resources in the underground, under the action of faults, the huge heat of geothermal resources is transmitted to the shallow surface to heat the shallow groundwater, and the heated groundwater and surface cold water form convective circulation, thus forming geothermal fields and even outcropping hot springs on the surface. Therefore, the development of hot springs is also an important indicator of the occurrence of geothermal resources.

Datong Basin is the main geothermal anomaly area in Shanxi Province. There are two underground hot water areas, located respectively in Tianzhen County and Yanggao County. There are many hot springs leaking points (in Figure 1b). Since the 1970s, geothermal wells have been discovered and drilled in Yanggao County and Tianzhen County in Datong Basin. The temperature of the water in these geothermal wells is between $28-104{ }^{\circ} \mathrm{C}$, as shown in Table 1. Among them, the geothermal well D1 with the drilling depth of $500 \mathrm{~m}$. The temperature at the bottom of the well is $104^{\circ} \mathrm{C}$. The average 
geothermal gradient is about $200^{\circ} \mathrm{C} / \mathrm{km}$, which is much higher than the geothermal gradient standard of $30-40^{\circ} \mathrm{C} / \mathrm{km}$. Therefore, it has the potential of geothermal resources development in Datong Basin.

Table 1. Geothermal wells in Datong Basin.

\begin{tabular}{cccccc}
\hline Sample Number & Sampling Position & Depth $(\mathbf{m})$ & Temperature $\left({ }^{\circ} \mathbf{C}\right)$ & Hydrochemistry Type & pH \\
\hline D1 & Guqianbao & 500 & 104 & $\mathrm{HCO}_{3} \bullet \mathrm{Cl}-\mathrm{Na}$ & 8.82 \\
D2 & Tangtou & 63 & 61 & $\mathrm{SO}_{4} \bullet \mathrm{Cl}-\mathrm{Na}$ & 8.81 \\
D3 & Fushan & 700 & 25 & $\mathrm{HCO}_{3}-\mathrm{Ca} \bullet \mathrm{Mg}$ & 8.26 \\
D4 & Yunmenshan & 172 & 43 & $\mathrm{HCO}_{3} \bullet \mathrm{Cl}-\mathrm{Na}$ & 8.19 \\
D5 & Dujiacun & 160 & 43 & $\mathrm{HCO}_{3} \bullet \mathrm{Cl}-\mathrm{Na}$ & 8.10 \\
D6 & Shangwuhuiguan & 80 & 38 & $\mathrm{HCO}_{3}-\mathrm{Na}$ & 7.89 \\
\hline
\end{tabular}

\section{Discussion}

The study of geothermal resources started early, but few people comprehensively analyzed and studied the distribution and formation mechanism of geothermal resources from the perspective of geothermal geology. This contribution makes full use of geological, geothermal, geophysical and drilling data to systematically study Datong Basin. It determines the genetic mechanism and geothermal geological characteristics of geothermal resources. The spatial distribution of heat source, heat conduction channel and heat storage system in Datong Basin is analyzed. It provides reference for the development of integrated research program of exploration, evaluation and exploitation of geothermal resources, and enhances the scientific nature and economy of exploration and exploitation of geothermal resources.

Geothermal resources are buried below the surface. It is difficult to evaluate directly except for drilling. The formation and occurrence of geothermal resources need certain geothermal geological conditions. Some geothermal geological characteristics are related to the formation and occurrence of geothermal resources. Therefore, through the analysis of these characteristics, we can analyze the genetic mechanism and determine the occurrence conditions of geothermal resources.

The occurrence areas of geothermal resources are mainly concentrated in volcanic activity areas, areas with thin crusts and the edges of global tectonic plates or tectonic lands, where magmatic activity and tectonic activity are intense. Plate tectonics have a fundamental influence on the formation of geothermal resources. Thermal state, heat flow, hydrogeological conditions, stress state, fault and lithology of rock strata are all controlled by the plate tectonic framework [8]. Based on the division of tectonic activity, the intensity of geothermal activity generally decreases with the distance from the plate boundary [12]. Neotectonic movement shapes the current geothermal resource background, and tectonic activities have important implications for the distribution of geothermal resources.

Otherwise, the locations where earthquakes occur are mostly in active crustal zones or active plate margins. They are coincided with the distribution of geothermal resources. Because of the high failure of rock fracture when earthquakes occur, these high-frequency seismic sites have strong tectonic activity and are likely to form geothermal anomalies. The formation of geothermal resources is closely associated with seismic activity in space, there is a certain sequence relationship in time, closely related in genesis, and has a certain spatial consistency in distribution.

The thermal source area of geothermal resources is usually characterized by low velocity and low resistance in geophysics. Magmatic intrusion can cause gravity-magnetic anomaly. The high permeability zone of geothermal resources reservoir can be identified by seismic wave-Poisson ratio anomaly area and P-wave attenuation area. Therefore, the conditions of geothermal resources thermal storage are characterized by low velocity, low resistance, positive gravity anomaly, and low magnetic susceptibility [39].

Through the analysis of tectonic setting, tectonic activities, geological structures, volcanic activities, geothermal geology and geophysical characteristics, it is obvious that Datong Basin is located at the edge of plate activity and is strongly influenced by neotectonic movement and seismic activity. 
The basin is characterized by intense magmatic activity, accompanied by magmatic intrusion, modern volcanic eruption and basalt development. Geophysical results show that there are partial melts with low velocity and low resistivity under the basin, and magma intrudes into the crust, forming high temperature anomalous bodies in the shallow part of the crust, providing a stable heat source for the formation of geothermal resources. The depth of the Curie isothermal surface in Datong Basin is shallow, the terrestrial heat flow value in the basin is higher than that in mountain area. The burial depth of Moho surface is shallower, hot springs are developed in the basin, and the value of geothermal gradient is higher, which meets the geothermal geological characteristics of geothermal resources formation. Therefore, the Datong Basin is an ideal target area for geothermal resources storage.

It is found that the magma forming the Datong Volcanic Group migrates along the NE direction; the seismicity in the basin is mainly concentrated in Yanggao, Tianzhen and Yangyuan areas in the northeastern part of the basin. The strike of deep and large faults basically distributes along NE. The hot fields, geothermal wells and hot springs in the interior of the basin are also mainly concentrated in Yanggao and Tianzhen areas in the northeastern part of the basin. According to the correlation between geothermal geological characteristics and the occurrence of geothermal resources, the distribution of geothermal resources in Datong Basin is mostly concentrated in the areas of Tianzhen, Yanggao and Yangyuan counties in the northeastern part of the basin (mainly the area where the deep-large faults converge).

The formation of geothermal resources in Datong Basin is affected by the collision between the Indian-Eurasian plate and the Pacific-Eurasian plate, causing the uplift of the Qinghai-Tibet Plateau and the destruction of the North China Craton, resulting in the lithosphere being more vulnerable to transformation, weakening and thinning, the asthenosphere upwelling, partial melting of the mantle, heat transfer from magmatic activity to the crust, and the shallow tectonic stress field reaching the intensity of crustal rupture. The heated crust extends laterally, the crust extends thinner and the heat source material upwells, which provides a stable heat source for the formation of geothermal resources. Then the deep-large faults in the basin form a good heat conduction channel, which transfers heat to shallow crust and form geothermal resources.

Datong Basin is located in the continental crust extensional fissure zone at the boundary of block activity. Where the crust is thinning, shallow buried magma (originated from asthenospheric mantle) sprays out from the surface under the action of neotectonic movement to form the Datong volcanic group, the upper mantle material arches, the crust shear thinning and rupture, resulting in magma eruption and overflow. The non-ejected magma from the surface migrates along the crustal fissures to the NE direction of the basin. The magma under the action of tectonic stress forms melt or semi-melt upward, which provides heat source for the formation of geothermal resources. Datong Basin is affected by the Qinghai-Tibet Plateau and undergoes an uplifting movement. Under the extensional cracking, the crust around Datong Basin is compressed and thickened, and secondary ridges appear in the basin. At the same time, the basin is located in a strong tectonic activity zone where the tectonic activity is relatively strong. The decompression melting occurs under the inter-plate compression (corresponding to the partial melt of the Tianshan area in the north of the basin shown in Figure 7). The magma rises along the tectonic faults, which also provides heat source for the formation of geothermal resources in Datong Basin. As a result, the genetic model of geothermal resources in Datong Basin may be formed by the combination of modern volcanic activity and the inner-plate active tectonic activities. The type of geothermal systems in Datong Basin belongs to magmatic geothermal systems, which is a combination of convective hydrothermal systems and partial melt systems, as shown in Figure 10. Because of the high temperature of shallow geothermal wells, for example D1 geothermal well the temperature is $100{ }^{\circ} \mathrm{C}$ when the depth is $500 \mathrm{~m}$, and with the depth increases the temperature may meet the occurrence of hot dry rock geothermal resources, which buried depth of $3 \sim 10 \mathrm{~km}$ and temperature above $150{ }^{\circ} \mathrm{C}$ [13]. Consequently, there may be hot dry rock geothermal resources in Datong Basin. In order to ascertain the possibility of existence and distribution of hot dry rock geothermal resources in the basin, further detailed exploration is needed. 


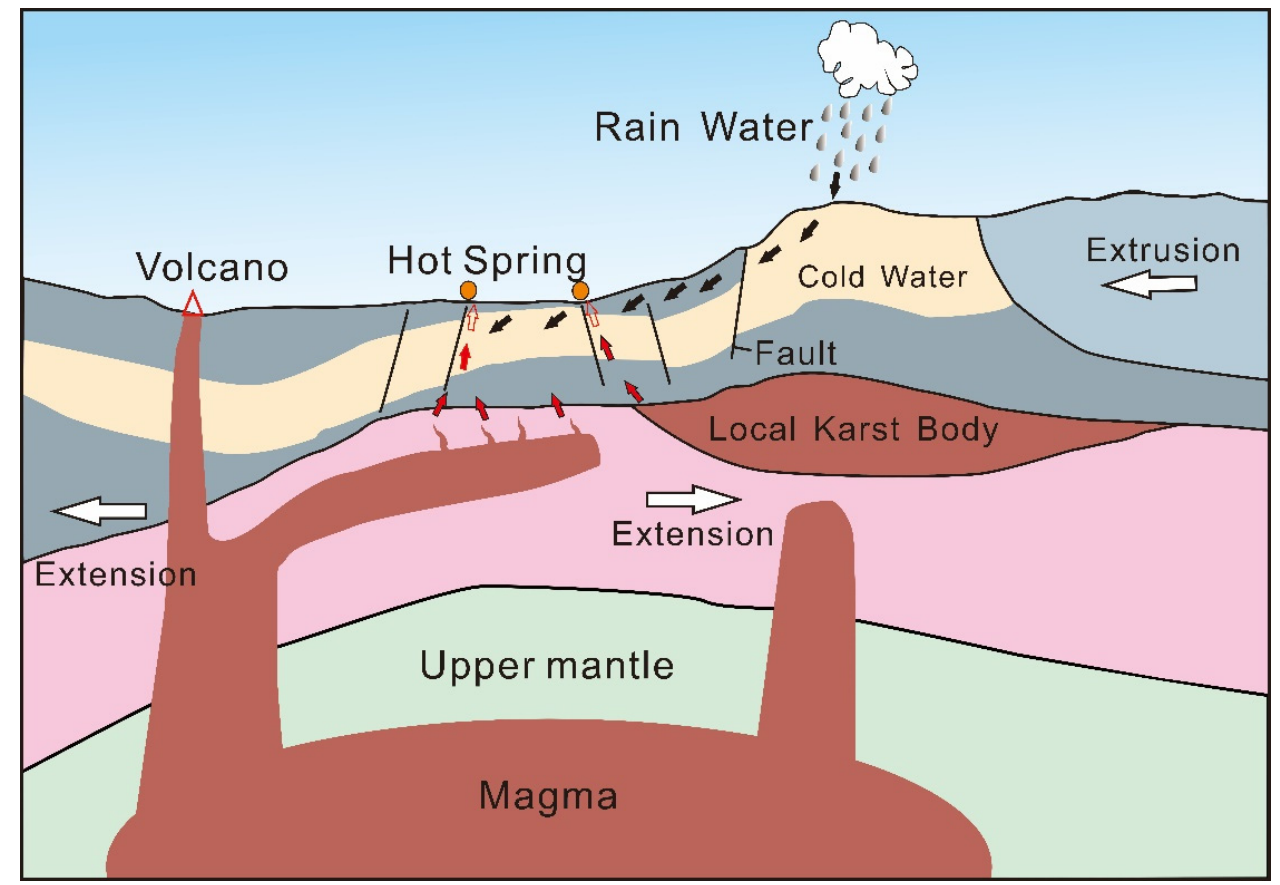

Figure 10. The genetic model of geothermal resources in Datong Basin.

\section{Conclusions}

The formation of geothermal resources generally occurs in areas with strong tectonic activities, seismic activity belts, and modern volcanic activity. Geophysical characteristics, terrestrial heat flow value, hot springs distribution and depth of the Curie isotherm surface are the geological geothermal characteristics that can judge the occurrence of geothermal resources.

Based on the analysis of the tectonic background, geophysical exploration results, volcanic and seismic activity activities, and the geological geothermal characteristics of Datong Basin, it is indicated that there are geothermal resources in Datong Basin, which mainly distribute in the northeastern part of the basin, Yanggao County, Tianzhen County and Yangyuan County, and it is recommended to carry out detailed and comprehensive exploration of the areas.

Geothermal resources in Datong Basin are likely be affected by the uplift of the Qinghai-Tibet Plateau and the destruction of the North China Craton, resulting in the thinning of the lithosphere, the upwelling of the asthenosphere and the partial melting of the mantle activity. The magma generated by partial melting surges, and some of them are erupted along the deep fault to form volcanoes on the surface, and the unexploded parts gather to provide heat source for the formation of geothermal resources in Datong Basin. The other part heats the crust and transfers heat to the earth's crust. Under the squeezing action between the plates, the crust is thickened, decompressed and melted, and the heat source material is uplifted, which also provides heat source for the occurrence of geothermal resources in Datong Basin.

The type of geothermal systems in Datong Basin belongs to magmatic geothermal systems, which is a combination of convective hydrothermal systems and partial melt systems. The genetic model of geothermal resources in the basin may be formed by the combination of modern volcanic activity and the inner-plate tectonic activities.

We should strengthen the theoretical research on the formation of geothermal resources, especially in the breeding environment, thermal structural system, distribution law, formation mechanism and thermal storage properties of geothermal resources. At the same time, seismic exploration, MT exploration and borehole exploration should be to carried out for further detail exploration in Datong Basin to determine the specific location and reserves of geothermal resources distribution in Datong Basin. 
Data Availability: The data used to support the findings of this study are available from the corresponding author upon request. The satellite gravity and magnetic data available in National Geospatial-Intelligence Agency.

Author Contributions: Conceptualization, W.Z. and X.H.; methodology, W.Z. and X.H.; software, W.Z. and S.L.; validation, W.Z. and W.C., S.L. and X.H.; formal analysis, W.Z.; investigation, W.Z.; resources, X.H., S.Y., H.G. and C.M.; data curation, W.Z.; writing-original draft preparation, W.Z. and X.H.; writing—review and editing, W.Z. and S.L.; visualization, W.Z.; supervision, W.Z.; project administration, X.H. and W.Z.; funding acquisition, X.H., H.G. and S.Y. All authors have read and agreed to the published version of the manuscript.

Funding: This study is jointed funded by National Natural Science Foundation of China (grant number 41630317), the National Key Research and Development Program of China (grant number 2018YFC0604303) and Fundamental Research Funds for the Central Universities, China University of Geosciences, Wuhan, China (grant number CUGCJ1707).

Conflicts of Interest: The authors declare that there are no conflicts of interest.

\section{References}

1. Lu, S.-M. A global review of enhanced geothermal system (EGS). Renew. Sustain. Energy Rev. 2018, 81, 2902-2921. [CrossRef]

2. Lin, W.; Wang, F.; Gan, H.; Ma, F.; Wang, G. Site selection and development prospect of a hot dry rock resource project in Zhangzhou geothermal field, Fujian province. Sci. Technol. Rev. 2015, 33, $28-34$.

3. Lu, C.; Wang, G. Current status and prospect of hot dry rock research. Sci. Technol. Rev. 2015, 33, $13-21$.

4. Sun, Z.; Li, B.X.; Wang, Z. Exploration of the possibility of hot dry rock occurring in the Qinghai Gonghe Basin. Hydrogeol. Eng. Geol. 2011, 38, 119-124.

5. Wang, G.; Lin, W.; Zhang, W.; Lu, C.; Ma, F.; Gan, H. Research on Formation Mechanisms of Hot Dry Rock Resources in China. Acta Geol. Sin. 2016, 90, 1418-1433.

6. Wu, C.; Hu, X.; Wang, G.; Xi, Y.; Lin, W.; Liu, S.; Yang, B.; Cai, J. Magnetotelluric Imaging of the Zhangzhou Basin Geothermal Zone, Southeastern China. Energies 2018, 11, 2170. [CrossRef]

7. Wang, J.; Hu, S.; Pang, Z.; He, L.; Zhao, P.; Zhu, C.; Rao, S.; Tang, X.; Kong, Y.; Luo, L. Estimate of geothermal resources potential for hot dry rock in the continental area of China. Sci. Technol. Rev. 2012, 30, 32.

8. Moeck, I.S. Catalog of geothermal play types based on geologic controls. Renew. Sustain. Energy Rev. 2014, 37, 867-882. [CrossRef]

9. Muñoz, G. Exploring for Geothermal Resources with Electromagnetic Methods. Surv. Geophys. 2014, 35, 101-122. [CrossRef]

10. Li, D.; Hao, H.; Liu, J.; Zhou, Y.; Chen, G.; Liang, S. The structure and mechanism of thermal disaster chains and the trend analysis of strong earthquakes in North China. Earth Sci. Front. 2013, 20, 102-108.

11. Li, D.; Wang, Y. Major Issues of Research and Development of Hot Dry Rock Geothermal Energy. Earth Sci. 2015, 40, 1858-1869.

12. Gan, H.; Wang, G.; Lin, W.; Wang, X.; Feng, M.A. Research on the occurrence types and genetic models of hot dry rock resources in China. Sci. Technol. Rev. 2015, 33, $22-27$.

13. Lu, C.; Lin, W.; Gan, H.; Liu, F.; Wang, G. Occurrence types and genesis models of hot dry rock resources in China. Environ. Earth Sci. 2017, 76, 646. [CrossRef]

14. Li, S.; Zhang, S.; Jia, X.; Tian, P.; Jin, X.; Zhang, C. Possibility of hot dry rock resources in Weishan volcano area of Wudalianchi. Sci. Technol. Rev. 2016, 34, 67-73.

15. Zhan, Y.; Zhao, G.; Wang, J.; Xiao, Q.; Tang, J.; Rokityansky, I. Crustal electric conductivity structure for Wudalianchi volcanic cluster in the Heilongjiang province, China. Acta Petrol. Sin. 2006, 22, 1494-1502.

16. Lin, W.; Liu, Z.; Ma, F.; Liu, C.; Wang, G. An estimation of HDR resources in China's mainland. Acta Geosci. Sin. 2012, 33, 807-811.

17. Gallagher, K. Thermal conductivity of sedimentary and basement rocks from the Eromanga and Cooper Basins, South Australia. Explor. Geophys. 1987, 18, 381-392. [CrossRef]

18. Genter, A.; Traineau, H.; Dezayes, C.; Elsass, P.; Ledésert, B.; Meunier, A.; Villemin, T. Fracture analysis and reservoir characterization of the granitic basement in the HDR Soultz project (France). Geotherm. Sci. Technol. 1995, 4, 189-214.

19. Mukuhira, Y.; Asanuma, H.; Niitsuma, H.; Häring, M.O. Characteristics of large-magnitude microseismic events recorded during and after stimulation of a geothermal reservoir at Basel, Switzerland. Geothermics 2013, 45, 1-17. [CrossRef] 
20. Stober, I.; Bucher, K. Enhanced-Geothermal-Systems (EGS), Hot-Dry-Rock Systeme (HDR), Deep-Heat-Mining (DHM). In Geothermie; Springer: Berlin/Heidelberg, Germany, 2012; pp. 163-176.

21. Yanagisawa, N.; Matsunaga, I.; Sugita, H.; Sato, M.; Okabe, T. Temperature-dependent scale precipitation in the Hijiori Hot Dry Rock system, Japan. Geothermics 2008, 37, 1-18. [CrossRef]

22. Kusky, T.M.; Li, J. Paleoproterozoic tectonic evolution of the North China Craton. J. Asian Earth Sci. 2003, 22, 383-397. [CrossRef]

23. Xu, X.; Ma, X. Geodynamics of the Shanxi rift system, China. Tectonophysics 1992, 208, 325-340. [CrossRef]

24. Cen, M.; Dong, S.; Shi, W.; Chen, L.; Chen, X. Structural Analysis on the Formation Mechanism of Datong Basin. Geol. Rev. 2015, 61, 1235-1247.

25. Li, S.; Zhao, G.; Dai, L.; Zhou, L.; Liu, X.; Suo, Y.; Santosh, M. Cenozoic faulting of the Bohai Bay Basin and its bearing on the destruction of the eastern North China Craton. J. Asian Earth Sci. 2012, 47, 80-93. [CrossRef]

26. Zhu, R.; Chen, L.; Wu, F.; Liu, J. Timing, scale and mechanism of the destruction of the North China Craton. Sci. China Earth Sci. 2011, 54, 789-797. [CrossRef]

27. Liu, M.; Cui, X.; Liu, F. Cenozoic rifting and volcanism in eastern China: A mantle dynamic link to the Indo-Asian collision? Tectonophysics 2004, 393, 29-42. [CrossRef]

28. Yin, A. Mode of Cenozoic east-west extension in Tibet suggesting a common origin of rifts in Asia during the Indo-Asian collision. J. Geophys. Res. Solid Earth 2000, 105, 21745-21759. [CrossRef]

29. Chen, L. Lithospheric structure variations between the eastern and central North China Craton from S- and P-receiver function migration. Phys. Earth Planet. Inter. 2009, 173, 216-227. [CrossRef]

30. Chen, L.; Cheng, C.; Wei, Z. Seismic evidence for significant lateral variations in lithospheric thickness beneath the central and western North China Craton. Earth Planet. Sci. Lett. 2009, 286, 171-183. [CrossRef]

31. Xu, X.; Zhao, L.; Wang, K.; Yang, J. Indication from finite-frequency tomography beneath the North China Craton: The heterogeneity of craton destruction. Sci. China Earth Sci. 2018, 61, 1238-1260. [CrossRef]

32. Zhai, M. Cratonization and the Ancient North China Continent: A summary and review. Sci. China Earth Sci. 2011, 54, 1110-1120. [CrossRef]

33. Wu, F.; Xu, Y.; Zhu, R.; Zhang, G. Thinning and destruction of the cratonic lithosphere: A global perspective. Sci. China Earth Sci. 2014, 57, 2878-2890. [CrossRef]

34. Zhu, R.; Xu, Y.; Zhu, G.; Zhang, H.; Xia, Q.; Zheng, T. Destruction of the North China Craton. Sci. China Earth Sci. 2012, 55, 1565-1587. [CrossRef]

35. Kearey, P.; Klepeis, K.A.; Vine, F.J. Global Tectonics; John Wiley \& Sons: Hobeken, NJ, USA, 2009.

36. Xu, Y.; Ma, J.; Frey, F.A.; Feigenson, M.D.; Liu, J. Role of lithosphere-asthenosphere interaction in the genesis of Quaternary alkali and tholeiitic basalts from Datong, western North China Craton. Chem. Geol. 2005, 224, 247-271. [CrossRef]

37. Yang, W. Continental extension and rifting reveled by worldwide comparison of crust and upper mantle structures. Geol. Rev. 2014, 60, 945-961.

38. Li, R.; Zhu, F. Formation and evolution of the Datong-Yangyuan basin. J. Palaeogeogr. 2000, 2, 92-96.

39. Shi, W.; Cen, M.; Chen, L.; Wang, Y.; Chen, X.; Li, J.; Chen, P. Evolution of the late Cenozoic tectonic stress regime in the Shanxi Rift, central North China Plate inferred from new fault kinematic analysis. J. Asian Earth Sci. 2015, 114, 54-72. [CrossRef]

40. Li, S. Morphotectonic setting of the development of Datong Volcano Groups in the eastern part of China. Acta Geogr. Sin. 1988, 3, 223-240.

41. Deng, J.; Mo, X.; Lin, P. Geological and petrological characters of Datong volcanic group. Earth Sci. 1987, 12, 233-239.

42. Zheng, H.; Xu, J. A Study and Comparison of Quaternary Mgneto-stratigraphy in Dotong Basin. Acta Geosci. Sin. 2001, 22, 418.

43. Li, D. Relevance of Seismicity and Geothermics: A New Thought to Alleviate Disasters from Earthquake Prediction to Taking Energy. J. Earth Sci. Environ. 2017, 39, 563-574.

44. Yang, W.; Zeng, Z.; Li, D.; Xing, J.; Wang, J.; Luo, W. Three-level tectonic model for intraplate earthquakes. Earth Sci. Front. 2009, 16, 206-217.

45. Zhang, C.; Zhang, X.; Gai, Y.; Zhao, J.; Nie, W.; Ren, Q. The crust-mantle velocity structure and deep tectonic in the Datong-Yanggao seismic region and its adjacent area. Seismol. Geol. 1998, 20, 391-398.

46. Dou, S.; Zhang, S. The relation between Quanternary volcano and earthquakes Activity in the Datong Basin. Bull. Inst. Crustal Dyn. 1996, 12, 52-58. 
47. Song, M.; Zheng, Y.; Ge, C. Relocation of small to moderate earthquakes in Shanxi Province and its relation to the seismogenic structures. Chin. J. Geophys. 2012, 513-525.

48. Zhang, H.; Huang, Q.; Zhao, G.; Guo, Z.; Chen, Y.J. Three-dimensional conductivity model of crust and uppermost mantle at the northern Trans North China Orogen: Evidence for a mantle source of Datong volcanoes. Earth Planet. Sci. Lett. 2016, 453, 182-192. [CrossRef]

49. Liu, B.; Zhang, X.; Zhang, C.; Song, S.; Zhou, X. Geological interpretation of S wave data along the Wen'an-Yuxian-Cahayouzhongqi profile in north China. Seismol. Geol. 2000, 22, 81-88.

50. Comeau, M.J.; Unsworth, M.J.; Ticona, F.; Sunagua, M. Magnetotelluric images of magma distribution beneath Volcán Uturuncu, Bolivia: Implications for magma dynamics. Geology 2015, 43, 243-246. [CrossRef]

51. Jiang, M.; Ai, Y.; Chen, L.; Yang, Y. Local modification of the lithosphere beneath the central and western North China Craton: 3-D constraints from Rayleigh wave tomography. Gondwana Res. 2013, 24, 849-864. [CrossRef]

52. Cammarano, F.; Goes, S.; Vacher, P.; Giardini, D. Inferring upper-mantle temperatures from seismic velocities. Phys. Earth Planet. Inter. 2003, 138, 197-222. [CrossRef]

53. Hieronymus, C.F.; Shomali, Z.H.; Pedersen, L.B. A dynamical model for generating sharp seismic velocity contrasts underneath continents: Application to the Sorgenfrei-Tornquist Zone. Earth Planet. Sci. Lett. 2007, 262, 77-91. [CrossRef]

54. Rychert, C.A.; Fischer, K.M.; Rondenay, S. A sharp lithosphere-asthenosphere boundary imaged beneath eastern North America. Nature 2005, 436, 542-545. [CrossRef] [PubMed]

55. Wang, G.; Zhang, W.; Liang, J.; Lin, W.; Liu, Z.; Wang, W. Evaluation of geothermal resources potential in China. Acta Geosci. Sin. 2017, 38, 449-459.

(C) 2020 by the authors. Licensee MDPI, Basel, Switzerland. This article is an open access article distributed under the terms and conditions of the Creative Commons Attribution (CC BY) license (http://creativecommons.org/licenses/by/4.0/). 